\title{
PENGATURAN NAVIGASI GERAK ROBOT 3 WHEELS OMNI-DIRECTIONAL MENGGUNAKAN METODE KONTROL PID
}

\author{
Rukmana Putra Marjanto \\ Program Studi Teknik Elektro, Universitas Hang \\ Tuah, Surabaya \\ yohanrukmana@gmail.com
}

\author{
Joko Subur \\ Program Studi Teknik Elektro, Universitas Hang \\ Tuah, Surabaya \\ joko.subur@hangtuah.ac.id
}

Abtrak - Robot adalah alat mekanik yang dapat melakukan kegiatan fisik, baik dengan pengawasan maupun dengan dikontrol oleh manusia, ataupun dengan pemrograman yang sudah dilakukan terlebih dahulu. Salah satu jenis robot adalah robot beroda, yaitu robot yang bergerak atau bernavigasi dengan bantuan komponen roda. Salah satu parameter robot beroda dapat dikatakan baik dalam bernavigasi apabila robot mampu menjaga jarak badan robot terhadap objek disekitarnya supaya tidak menyentuh atau tertabrak. Pada penelitian ini telah dilakukan pengujian dalam pengaturan navigasi gerak robot beroda dengan menggunakan 3 roda omni atau dapat disebut juga robot 3 wheels omni-directional untuk menjaga jarak badan robot sisi kanan terhadap objek dinding dengan metode kontrol Proportional, Integral, Derivative (PID). Kontrol PID bekerja berdasarkan nilai setpoint jarak yang diharapkan pada robot terhadap dinding, nilai setpoint akan dibandingkan dengan masukan data jarak badan robot terhadap dinding yang dihasilkan oleh sensor jarak SRF-05 yang terpasang pada robot. Dari perbandingan tersebut maka akan didapat nilai selisih atau error, nilai selisih tersebut untuk proses perhitungan berikutnya dengan parameter Kp, Ki, Kd dan akan didapatkan nilai hasil perhitungan PID untuk menggerakkan roda dengan memberikan sinyal Pulse Width Modulation (PWM) pada masing-masing roda. Dari hasil pengujian trial and error didapatkan nilai parameter kontansta PID sebesar: $K p=30, K i=10$ dan $\mathrm{Kd}=\mathbf{2 0}$, dengan hasil robot mampu bernavigasi dengan baik tanpa menyentuh dinding dengan jarak setpoint robot terhadap dinding terkecil jarak $10 \mathrm{~cm}$.

Kata kunci: Robot beroda, Gerak navigasi, kontrol PID, jarak setpoint

\section{PENDAHULUAN}

Perkembangan teknologi saat ini sangat pesat, demikian pula dengan perkembangan teknologi elektronika. Robotika merupakan bukti peradaban manusia yang semakin maju dari waktu ke waktu. Wujud robot bukan hanya sebuah bentuk yang menyerupai manusia atau binatang tertentu yang bergerak menyerupai bentuk yang ditirunya. Robot pada dasarnya merupakan suatu sistem terintegrasi yang membuat sebuah sistem mampu mengerjakan suatu tindakan berdasarkan masukan yang diterimanya [1].

Pada saat ini, bidang elektronika sangat dibutuhkan, sebab di dalam bidang ini terdapat beberapa sistem yang dapat membantu mempermudah pekerjaan manusia. Perkembangan teknologi robotika telah mampu meningkatkan kualitas maupun kuantitas produksi berbagai pabrik. Selain itu, meningkatkan kreativitas manusia yang sangat antusias dalam merancang dan membuat robot yang tentunya mempunyai tujuan untuk lebih mempermudah manusia dalam melakukan pekerjaan atau aktivitasnya sehari-hari.

Robot adalah alat mekanik yang dapat melakukan kegiatan fisik, baik dengan pengawasan maupun dengan dikontrol oleh manusia, ataupun dengan pemrograman yang 
sudah dilakukan terlebih dahulu. Robot biasanya digunakan untuk melakukan tugas berat, berbahaya, melakukan pekerjaan yang berulangulang dan kotor. Kebanyakan robot industri digunakan dalam bidang produksi. Belakangan ini robot tidak hanya digunakan dalam bidang industri, tapi sudah memasukin pasar konsumen dibidang hiburan dan pembantu alat rumah tangga seperti penyedot debu, dan pemotong rumput.

Tahun 2015 terinspirasi oleh Maha-siswa di Jakarta ditemukan alat yang disebut Robot Pembersih Lantai Berbasis Arduino Uno Dengan Sensor Ultrasonik, dari hasil pengujian robot yang telah dibuat me-ngalami pergerakan robot menjadi tidak stabil yang dikarenakan torsi robot yang tidak sebanding dengan berat robot sehingga pergerakan pada robot tidak dapat berbelok 90 derajat[2].

Pada penelitian ini dikembangkan menggunakan kontrol PID (Proportional, Integral, Derivative) dalam mengatur kecepatan putar motor untuk penggerak roda pada robot. Robot bekerja dengan cara menyisir ruangan secara otomatis tentunya dengan setpoin yang telah diatur sebelum-nya.

\section{BAHAN DAN METODE}

Robot pembersih lantai adalah robot autonomous yang bergerak mencari jalan dan membersihkan ruangan yang kotor. Robot yang dibuat mampu membersihkan celah yang susah dibersihkan dan di-jangkau. Robot pembersih ini bergerak secara otomatis dengan menggunakan arduino sebagai otak robot. Robot ini bisa bergerak maju sampai bertemu halangan berupa tembok maka robot/ alat ini akan berbelok ke kiri otomasis sebesar 30 derajat untuk menghindari halangan dan terus mem-bersihkan lantai yang belum di bersihkan.

\section{Arduino Mega 2560}

Arduino adalah sebuah sebuah kit atau papan elektronik yang dilengkapi dengan software open source yang menggunakan keluarga mikrokontroler ATMega dan berfungsi sebagai pengendali mikro single-board yang dirancang untuk memudahkan penggunaan elektronik dalam berbagai bidang yang dirilis oleh Atmel. Arduino mega 2560 memiliki 54 pin digital input/output, dimana 15 pin dapat digunakan sebagai output PWM, 16 pin sebagai input analog, dan 14 pin sebagai UART (Port serial Hardware), selain itu arduino mega ini juga memiliki $16 \mathrm{MHz}$ kristal osilator, tombol reset, header ICSP, koneksi USB dan jack power[3].

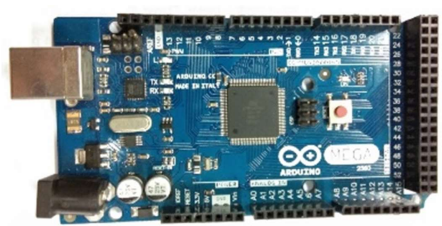

Gambar 1. Arsitektur Arduino Mega 2560

\section{Driver Motor IC L298N}

L298N adalah komponen elektronik yang dipergunakan untuk mengontrol arah putaran motor DC. Satu buah L298N bisa dipergunakan untuk mengontrol dua buah motor DC. Selain bisa dipergunakan untuk mengontrol arah putaran motor DC, L298N ini pun bisa dipergunakan sebagai driver motor Stepper bipolar[4].

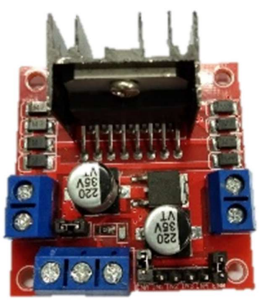

Gambar 2. Modul L298N

\section{Motor DC}

Motor DC adalah jenis motor listrik yang bekerja menggunakan sumber tegangan DC. Arah putaran motor DC ditentukan

oleh arus maju atau arus berbalik atau tegangan positif dan tegangan negatif pada motor DC. Sedangkan kecepatan motor DC ditentukan oleh perubahan/meningkatnya tegangan kumparan pada motor DC tersebut[5].

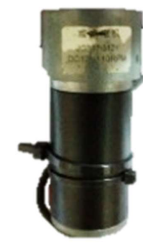

Gambar 3 Motor DC gearbox 12V

Catu Daya 
Catu daya memegang peranan yang sangat penting dalam hal perancangan sebuah payload. Pemilihan catu daya yang tepat akan menghasilkan payload yang bekerja dengan baik. Baterai yang digunakan pada perancangan payload ini berjenis lithium polymer (LiPo). Baterai ini dapat diisi ulang (rechargeable). Baterai yang digunakan memiliki tegangan 11,1 Volt dan arus sebesar 4200 mAh dengan 3 cell di dalamnya.

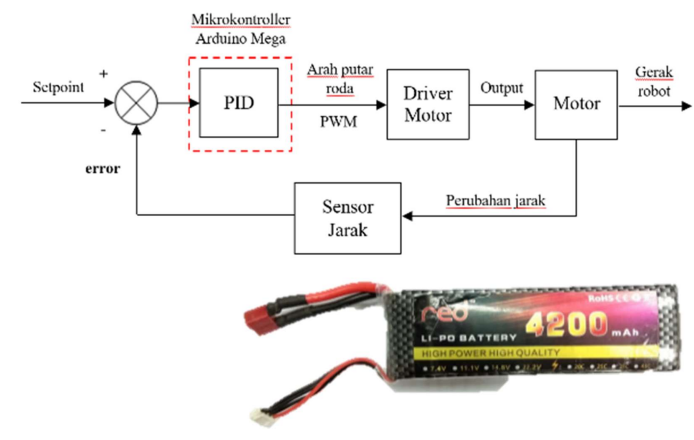

Gambar 4 Li-Po Battery

\section{Sensor Ultrasonik HY-SRF05}

Sensor HY-SRF05 adalah sensor pengukur jarak berbasis gelombang ultrasonik. Prinsip kerja sensor ini mirip dengan radar ultrasonik. Gelombang ultrasonik dipancarkan kemudian diterima balik oleh receiver ultrasonik. Jarak antara waktu pancar dan waktu terima adalah representasi dari jarak objek. Sensor ini cocok untuk aplikasi elektronik yang memerlukan deteksi jarak termasuk untuk sensor pada robot[6].

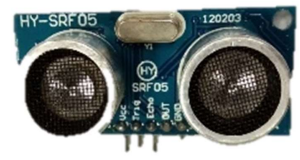

Gambar 5 Sensor HY-SRF05

\section{Sistem PID}

Kontrol Proportional, Integral, Derivative (PID) adalah sistem pengendali yang umum digunakan di industri maupun militer. Sekitar $90 \%$ dari peralatan industri menggunakan pengendali PID karena mudah digunakan dan paling sederhana. Kontrol Proportional (P), Integral (I), dan Derivatif (D) dapat digunakan bersamaan secara paralel ataupun digunakan terpisah dengan tidak menggunakan salah satu komponen P, I atau $\mathrm{D}[7]$.

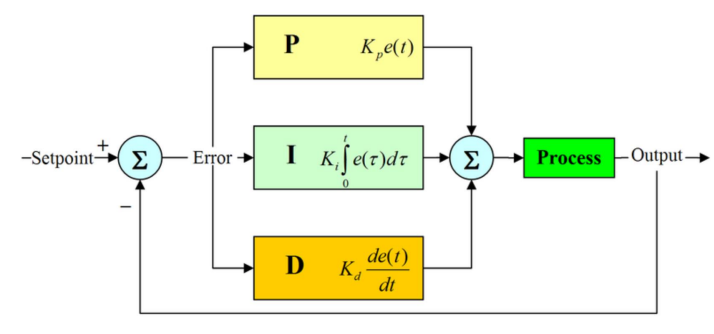

Gambar 6 Blok Diagram Kontrol PID

\section{Perancangan Perangkat Keras}

Untuk memberikan penjelasan lebih lanjut tentang tugas akhir ini penulis akan menjelaskan sistem pergerakan robot pembersih lantai menggunakan metode Proportional Integral Derivative (PID) yang akan dibuat pada tugas akhir ini, berikut adalah gambar diagram blok dari sistem alat ini:

Pada penelitian ini akan dibuat sebuah sistem kontrol PID dengan modul driver L298N yang tiap modul itu sendiri dirancang secara paralel untuk tiap motor pada robot. Kontroler PID bertujuan untuk mengatur kecepatan bernavigasi saat robot jauh atau dekat dengan dinding. PID bekerja terhadap dinding atau halangan untuk meluruskan posisi robot dengan dinding. Jadi robot saat berjalan menyisir dinding ruangan akan menjaga jarak terhadap dinding sesuai setpoin yang telah diatur sebelumnya. Penentuan hasil parameter kontroler PID ini didapatkan dengan menggunakan metode trial and error. Hasil parameter kontroler

PID yang dicapai dari penelitian ini akan diperoleh nilai $\mathrm{Kp}, \mathrm{Ki}$, dan $\mathrm{Kd}$, sehingga diharapkan robot pembersih lantai akan bernavigasi dengan baik. Dari diagram blok sistem dan dan diagram blok sistem PID tersebut, maka akan dijadikan satu kesatuan berupa diagram alir/ Flowchart sistem agar mudah untuk menganalisis cara kerja keseluruhan sistem pada alat ini. Berikut dibawah ini merupakan gambaran diagram alir / flowchart. 